\title{
10 Patina meets fashion: on the evaluation and devaluation of oriental carpets
}

FABIAN FAURHOLT CSABA AND GÜLIZ GER

This chapter examines how different actors account for the quality and value of oriental carpets. It introduces the subject matter through three case examples: how an auction house expert approaches establishing the market value of carpets; how a dedicated rug collector accounts for his tastes and tactics; and how a quality controller goes about rating the season's work of a village weaving cooperative dedicated to the revival of craft traditions. The evaluative practices of the actors reflect a field that values age and tradition, rather than novelty and creativity, but also a field in decline. In this sense ours is a special case of the evaluation of creativity.

The chapter reconsiders and applies Grant McCracken's (1988) concept of patina in the analysis of how, why, and the ways in which signs of age are valued in oriental carpets. We examine closely how the material properties, processes, and affordances of oriental carpets lend themselves to symbolic uses and judgments of value. Acknowledging that material properties reflecting wear, tear, and care are judged differently, we present a matrix that discerns four approaches to the perception and appreciation of oriental carpets. While sharing some common ground, each approach appraises carpets according to a particular set of criteria and techniques, and privileges certain names, categories, or genres of oriental textiles, while devaluing others. Actors apply such schemes in identifying, appreciating, and evaluating the combinations of the physical properties - patina and others - of carpets.

Although the devaluation of oriental carpets appears to confirm McCracken's claim that patina all but lost its significance with the rise of fashion in the modern era, we seek to demonstrate that the concept of patina might still inform analyses of contemporary cultural markets and products. Not only does the analysis of patina provide a lens through which to explore the connections between material and symbolic properties of cultural objects which are vital for understanding and determining 
their value, we also suggest that rethinking the relationship between patina and fashion offers new perspectives on how signs and concepts of age and novelty factor into judgments of the appreciation of creative and cultural products.

\section{'What is it worth?' An exceptional carpet under the hammer}

On September 7, 2007, an antique Persian carpet reached a hammer price of $€ 135,000$ at the leading auction house in Denmark. The amount not only set a new record for an oriental carpet in Denmark, it was a staggering fourteen times the estimated sales price. The auction houses carpet specialist, Frederik, who is also on the board of the Danish Rug Association, recounts his experience with the fine rug:

It was strange ... it came from some estate in Jutland. One of my colleagues got it from this estate and he sent me a picture of it and I told him, 'You know what, send it over to me! It ought to be sold over here.' And when I rolled it out, I could see it was of a real fine quality. It was quite out of the ordinary. Then I showed it to one of my colleagues - a former carpet dealer with many years of experience in the business. And he was also almost bowled over. Then, I realized as the day of the auction approached and inquiries were made about it ... and those making the inquiries ... When you know some of the real big names are asking about it, you know it has the potential for going really high.

The item was a pictorial rug from Kerman in Iran measuring $270 \times 164 \mathrm{~cm}$. With a knot count of about 700,000 knots per square meter, this means that it is made up of some 3 million knots. Its design depicts fruit trees with a variety of birds on the field and animals and portraits of male figures of different nationalities on its main border. Woven inscriptions identify who ordered, designed, and executed the carpet and date it to $1336 \mathrm{AH}$, which corresponds to 1908. The auction catalog identified the carpet in detail, described it as a 'unique masterpiece,' and estimated it at $€ 10,000$. Auction houses may deliberately set the estimated price attractively (low) in order to encourage more buyers to attend in the hope of making a good deal, and thereby help spark a bidding contest. But the auction house expert readily concedes that the estimated price was set too low. Later he discovered that a similar carpet had been sold a couple of years earlier at Christie's for about $£ 120,000$, and even if the prime Danish auction house is 'not Christie's' and cannot 
attract quite the same clientele of top international buyers, the expert feels he ought to have factored previous international auction prices into his estimate. He still marvels at the carpet's details when asked to explain its qualities and value:

Exceptionally fine quality: excellent condition, then the overall impression, and when you went in and looked at the birds ... really, when you saw how nuances had been knotted into the fruits, if you imagine, it was as if there was an inflow of light from one side. That was the impression one got looking at that apple, you know. The inflow of light was almost knotted into it, you see. And like, unique and rare ... that's a big part of it. So there were four or five factors that in combination made it so attractive.

While attesting to the enduring appreciation of oriental carpets in the West, the recent record price does not signal a healthy market for fine hand-woven carpets in Western Europe. Indeed, the interest in traditional home furnishings and antiques in general, and oriental carpets in particular, has been diminishing. This, and the discrepancy between the pre-auction estimate and the hammer price, seems to confirm widespread notions about the opaque and erratic nature of the market for oriental carpets. It is not only novice buyers who find themselves bewildered, even experts at times have difficulty determining the monetary value of rugs.

The record bid in Denmark came from an American dealer, who believed that he would be able to resell the carpet at a profit to a customer after a few years. But what might possess a private collector, not necessarily a very wealthy one, to spend extraordinary sums on old floor coverings? How are such inclinations developed? Consider the account of an avid American collector, who has built a world-class collection in his special field of interest, on how his passion and addiction developed.

\section{Developing a passion and addiction}

Harry is a naturalized American of British origin and an accomplished academic who travels frequently. He was introduced to oriental carpets through his wife-to-be's carpets - which he now considers to be 'junk' that she received as gifts while working in Turkey in the late 1960s. Harry now has a collection of 200 exquisite pieces, bought across the US and Europe. 
He recalls with pride his first steps to becoming a collector and explains how he started pursuing his newly realized passion for color:

One of my first two pieces I bought from a picker in Chicago, in the 1970s. Not in good shape. A Malayir medallion, corroded celadon green, earth colored apricot. I was more interested in color, I was a color person. I loved the Malayir: the colors, design of the field was medallion, like the Kuran, simple border. I loved the elegance of the simple border on the earth colored apricot. The green was lower than the rest; the 3D texture was wonderful.

After reading about carpets, he decided to collect 'narrowly': only from a very small part of Iran - Fars, nomadic, Quasghai (a Turkic tribe) and a certain era, 1870-1910. He collects carpets and any textile from that era, 'when rugs were being made and exported to Europe in great quantities from Iran,' and when all wool was handspun and all dyes natural. The introduction and rapid spread of synthetic dyes and machine-spun yarn in the late nineteenth century, even to the most remote regions, carried the seeds of decline of the oriental carpet in terms of aesthetic and technical quality, as well as 'authenticity.' While this development was instrumental in the producers' attempts to meet increased Western demand, it obstructed the art of oriental carpets since these carpets entailed less variation, known as 'abrash' and 'variegation' in the colors (Eiland and Eiland 1998: 51) and the resultant regularity of structure, surface, and color left discerning buyers disenchanted. Moreover, these dyes faded unsatisfactorily and the fade is an important aesthetic dimension of oriental carpets. Eiland and Eiland (1998: $60)$ note that synthetic dyes 'represent one of the rare examples in which modern science has, at least so far, failed to match traditional standards.' Carpet connoisseurs like Harry gradually turned their interest exclusively toward older, naturally dyed carpets, which as time passed became more and more rare and expensive. Hence, rugs produced in the past are idealized and narratives of declining standards underpin judgments of their cultural and market value.

The depth (and price) of Harry's passion became evident to himself and his wife in the late 1970s.

One decision that was truly momentous in retrospect: an exhibition in London, I think it was 1978, of late nineteenth-century Quasghai rugs, for sale in relation to the book Woven Treasures. I heard about the book, then went to London, and bought the cover rug from the book. Which knocked my socks off. So did fifteen other carpets from the show. I paid one third of a year's salary. Huge 
amount of money, my darling wife let me know it. The place was sky high. Dollar was weak, 2.4 to the pound. 7,000 pounds $-17,000$ USD. Too high a price! But I loved the rug. I was making a commitment to myself as a collector. Then I knew that I was willing to pay fortunes for carpets. I realized my commitment. Next day there was an auction. I bought another carpet, same quality, for 30 percent cheaper. I started thinking about the price differential. After that day, I never overpaid for any carpet. On my way back from London I thought, I am the owner of two world-class carpets.

To his disappointment, his wife reacted 'not very positively,' yet she tolerated his passion. Harry laments that 'she has been interested in rugs on the floor, not as art' and that, unlike other collectors' wives who are interested and go to conventions and exhibitions with their husbands, his wife does not: 'I feel very sad about that. That we could not participate as couples. I am known as a quiet outsider, not an insider.'

Harry is also disheartened by the diminishing interest in fine oriental carpets, experienced by Frederik. 'It breaks the heart of the collector to look at Architectural Digest,' he laments, suggesting that now maybe one of twenty of homes represented have rugs. Ten years ago, he reckons the ratio was eight out of twenty, fifteen years ago sixteen out of twenty. Harry also points to the adverse influence of interior design:

The interior decorator business likes sleek, modern lines. Marble and wooden floors for which you pay a fortune - you want the floor to be seen. Carpets are regarded as fussy, not sleek and modern. Now people want expensive furniture and paintings to dominate a room rather than carpets.... Young people are socialized to a different taste. No one under 40-45 buys rugs any more.

The carpet trade has responded in ways that disturb the admirer of oriental craft traditions. 'So in many countries carpet producers turned over backwards and are making carpets that are oriental in structure but not in design - monochromatic or few colors.' The growing influence of contemporary design and interior decoration trends, in other words, plays a key role in eroding demand at least in the general or decorative market as opposed to the collectors'.

\section{Just like the old}

In response to the realization of the adverse effects of compromises in the craft, there have been initiatives aimed at keeping alive and reviving local carpet production and craft traditions. One of them involves the 
Turkish-based German chemist Harold Böhmer, who has applied modern spectrographic analysis to rediscover natural dyes and helped spark a series of initiatives in Turkey (Csaba and Ger 2000; Eiland 1993; Ger and Csaba 2000; Opie 1998). Together with Marmara University, Böhmer co-founded the DOBAG project, a cooperative in Western Anatolia. DOBAG reproduces the designs of the region around Çanakkale, Ezine, Bergama, and Manisa. According to Böhmer:

We do the designs of the last 100 years. This is a work that lives here, continuation of living traditions. Besides, these designs that weavers have always made, we have them make in different colors. The only difference (from the 100-year-old carpets) is the difference in colors.

Serife Atlihan, the university professor in charge of quality control and general supervision, gives examples of how she and Böhmer seek to guide the weavers in the cooperative:

We say, use white sparingly. White does not look beautiful, the gaze is captured by the white, too bright. The customers say so, too. We say, don't put yellow and green next to each other. Yellow is used after the indigo to make green. When they are adjacent, yellow appears too strong.... We did research on aesthetics, the color combinations of old carpets. They never used yellow and green next to each other.

Böhmer and Atlihan's evaluation criteria emphasize the technical qualities and the neatness of the weave and the cut. Atlihan grades each carpet by examining the front and the back carefully. She gives three grades: super, 1 , and 2, but gives 2 rarely. On one occasion when we were accompanying her, she rated eighteen of the thirty-five carpets as 'super.' The earnings of the weavers depend on these ratings. Explaining what 'neat' is, Atlihan shows us a rug:

Look, the back is dirty. Threads are hanging. The weaver did not cut them out properly. We tell them 100 times. They do it in a hurry and leave it (without properly finishing it)... That one, the sides are too tight, makes the carpet look like lettuce leaves. Have to knot the tassels twice... Not using the scissors properly, putting in an extra thread, the ends pulling, wavy ends and sides, lettuce, that's bad. The worst is when there is a fold, like lettuce. Then it ages badly. Inserting one thread loosely, one tightly makes a lettuce. Have to feed in at the same tightness... This one, the trimming is good, the cut is good, the technique is good, this is 'super.' But the side is a bit crooked, not a big problem. When the whole is very beautiful, little errors can be tolerated. 
In addition to the neatness of the work, the designs are important. Responding to our inquiry about aesthetics, she says:

The top border on this one is too narrow.... That one, the patterns in the middle are too intertwined. When there are three large patterns in the middle, it is better to have tiny designs around it; the medium-size designs are too much. Small ones make it more spacious, open.

She also checks the proportion of the length and the width: 'Too short or too narrow is not suitable for living rooms. People want to place carpets in the middle of a room, not under the furniture.'

DOBAG carpets are sold internationally, but demand is declining. While some customers adore DOBAG carpets, others are less enthusiastic. An American scholar of Turkish folk art suggested: 'In Çanakkale, Balıkesir, Manisa women were weaving, hand spinning and making natural dyes before Böhmer. Very beautiful carpets too. Now with Böhmer and Atlihan's strict control, some DOBAG carpets are becoming stale, stiff, boring.' A Turkish dealer concurs: 'DOBAG was an exciting project. But they lacked something. They could not achieve the same researcher-scholar-creative dynamism they showed in dyes and colors in creating a variety in designs and sizes. Hundreds of look-alike small carpets.' So, producing carpets 'just like the old' may not always work well, at least not in this case, even though the once-lost techniques are reinvented.

\section{Signs of age and value: beyond patina?}

For the mass of society, the notion of patina is itself hopelessly antique, a charming notion that has passed from fashion. Patina, if it lives on, does so in tiny social enclaves where it keeps the gate with all its former perspicuity but precious little of its former glory. (McCracken 1988: 43)

Why are older carpets highly valued, but less so than in the past? Which material properties in rugs are appreciated and why?

McCracken's theory of patina (1988) seems like a pertinent framework in which to address issues of evaluation and devaluation raised in our case of the market for oriental textiles. His analysis accounts for the physical properties or processes of aging and explains their symbolic significance and social function. For McCracken, patina reflects conditions under which value and status are represented by things that are old, rather than new. Such conditions prevailed in medieval and early 
modern Europe, where the 'patina' system of consumption and status representation enjoyed its heyday, before being eclipsed by fashion, without entirely disappearing in the modern world.

Some of the material processes and properties that are valued in judgments of oriental textiles - such as the softening of colors, natural corrosion of pile, and integrity of structure, material, and design - can be understood as patina. Arguably, the golden age of oriental carpets was in the medieval and early modern period. In this era, rugs were among the most potent symbols of power and status (as evidenced in the display of oriental carpet in portraits of Europe's ecclesiastical and aristocratic elites) and the craft reached its highest level of acclaim and sophistication. Despite periodical and regional revival, the oriental carpet art and market has been in decline ever since and now, as patina, shows little of its former glory. So apparently McCracken's theory of patina is applicable to oriental carpets and offers explanations for the valuation, as well as the long-term devaluation, of these cultural artifacts. In the following section, we will first review the main elements in McCracken's theory of patina and address the limitations of interpreting oriental carpets solely in terms of patina. Then we suggest ways to extend and revise McCracken's analysis of patina - in ways that inform evaluative practices in cultural and creative industries.

\section{Patina and the representation of status}

In his essay 'Even dearer in our thoughts - Patina and the Representation of Status before and after the Eighteenth Century, consumer anthropologist McCracken (1988) advances the concept of patina as a key to understanding strategies of status display and historical shifts in systems of consumption. Patina is a material property - the small signs of aging such as dents, chips, oxidization, or being worn away that accumulate on the surfaces of objects of human manufacture over time, due to exposure to the elements or other aspects. He describes poetically how a thing's 'original surface takes on a surface of its own' (1988: 32), capturing how objects in the process of patination are singularized and develop an identity. But these alterations of surfaces have symbolic significance, serving as evidence of the status of the owner. Patina does not communicate status directly but - more subtly - authenticates it. By suggesting how long the object has been in the possession of the owner's family, patina enables distinctions between old and new wealth. In early modern 
England, wealth might have been able to buy individuals all the trappings of the nobility, but escaping the stigma of commonness took time, a long time - several generations, in fact. The accumulation of patina was an effective public indicator of how far along the long path to gentle standing a family was.

McCracken argues that patina was an effective vehicle for communicating social distinction. Since it reproduces some of the qualities of the thing it signifies, patina represents an iconic sign (in Charles Sanders Peirce's scheme). The accumulation of this sign of age on family possessions, in other words, signifies the duration of that family's claims to wealth. Obviously, patina's communication of status depends on a string of assumptions and inferences observers make about the individuals' status claims: patina expresses the age of an object; the object's age reflects the duration it has been in a family's possession; the possession of the object indicates a considerable discretionary income, which in turn suggests an elevated social status (McCracken 1988: 36). The iconic relationship between the signifier and the signified facilitates the inference of patina as a measure of true status. The connection is natural and motivated, rather than arbitrary. Appadurai (1996: 73-74) calls this transfer 'the subtle shift of patina from the object to its owner or neighbor,' and notes that this process can be fully accomplished only in a context of felicitous conditions.

McCracken considers patina strategies in relation to three other systems of status display and verification: sumptuary laws regulating consumption practices according to class status; possession of closely guarded insignia and seals as proof of class status; and 'invisible ink' strategies - the cultivation of certain kinds of knowledge, which serve as the primary indicators of group affiliation. The patina system has the advantage (over the former two) of not requiring a central authority to issue and reinforce rules or official signs of rank. Every social actor is able to approximate status and immediately tell apart legitimate from fraudulent status claims. However, since patina's status symbolism is better understood by those in established, elevated positions of status, it has the same advantage as the 'invisible ink' strategy in operating as a 'hidden code immediately intelligible to those of genuine standing and well concealed from all but the most sophisticated pretenders' (McCracken 1988: 35). Patina, though, is more robust than the 'invisible ink' strategy, which, according to McCracken, works best in confined, static social environments. 
The patina system was eroded by the acceleration of fashion and its expansion to a range of product categories (including houses and home furnishings) with the consumer revolution in eighteenth-century England. As new products and tastes emerged and became status markers, patina offered no protection for high-standing social groups. This set in motion a dynamic of constant superordinate innovation, rapid trickle-down, and subordinate emulation. Since then, fashion has reigned as the dominant system of status representation, and patina has played an ever more marginal role.

For McCracken real patina objects are non-exchangeable: they lose their power if they are acquired. In other words, they are inalienable 'extensions of the family,' to paraphrase Belk (1988). Patina shifts from object to owner, from material property to status marker, only as long as it stays in the possession of the family. However, this comes across as a very narrow conception of patina, which forecloses further exploration of patina strategies in the modern era. McCracken does not go into any detailed investigations of cases of patina, neither their materiality in particular products nor of detailed studies of how 'subtle shift of patina from the object to its owner' worked in practice.

So, how might the analysis of patina be applied in studying the physical and symbolic properties and evaluation of oriental carpets? Rather than assuming that patina objects are inalienable, or at least lose their value as status markers outside the family, we suggest that patina on objects might have a sign value for others and that patina objects do have (independent) cultural and economic value. Ultimately this will lead us to question whether patina has been eclipsed by fashion and is of negligible significance today. We believe that a more open conception of patina might lead to the reconsideration of what impact patina and similar material properties have on the meaning and value of objects, beyond their ability to (in)validate status claims in hierarchical societies of the past. Drawing on and moving beyond McCracken's inquiry, we now return to the case of oriental carpets.

\section{Patina and oriental carpets}

We have seen that while the market for oriental carpets has been in decline, higher prices for top-range carpets, as well as trends favoring certain types, suggest a more complicated picture. As the production of non-industrial-quality carpets has dwindled, supply has depended 
on older carpets re-entering the market. Since the older carpets gradually wear out beyond repair and restoration, the stock of old carpets constantly shrinks. As the number of fine carpets in good condition gets scarcer, prices increase. Periodically, the market is revitalized by the (re)discovery of previously neglected types of oriental textiles. Such trends tend to change tastes and patterns of demand. It also makes oriental carpets more susceptible to fashion and design trends. Nevertheless, oriental rugs are no longer among the primary markers of taste and status, and consequently have lost much of their appeal as objects of trade and investment. While a community of dedicated collectors, scholars, and dealers continues to share members' knowledge and passion for rugs, the interest and appreciative skills in the field are not being adopted by younger generations enough to reproduce market demand. However, markets are dynamic and demand is based on the fashions and trends that define the desirability of a good, as much as the features of that good. Oriental carpets are no exception. It is not unreasonable to expect that when home-decoration fashions change, the oriental carpet market will also change.

Regardless of levels of demand, we believe that the analysis of patina needs to deal more closely with the material properties of cultural goods and explore their connection to the symbolic meanings and values of these goods. McCracken implies that patina can occur naturally, or can be a result of human use, and assumes patina to be a fairly accurate and transparent indicator of the age of objects, which enables it to act as evidence of duration of ownership. But his lack of engagement with material properties leaves a number of questions unanswered: do all signs of age constitute patina? Does patina signify things other than age? What if signs of age result from human efforts to advance, delay, or restore patina? Does patina refer only to the desirable signs of age? If so, which signs of age are desirable, and, as Appadurai (1996: 75) puts it, how might we distinguish wear from tear?

The material properties of oriental carpets help illustrate some of these issues. We have seen how color is a key factor in the evaluation (and devaluation) of oriental carpets. As Eiland and Eiland (1998: 50) point out, 'the rug's appearance and manner in which it ages are to a large extent dependent on the dyes that have been used' and, when carpet making relied on complicated methods of natural dyeing, the cost of dyes is likely to have matched that of the wool. Dyes differ in their 
color fastness and the long-term effect their application has on the wool. Colors tend to fade or otherwise change with exposure to light or abrasion. Colors may bleed when exposed to moisture and the dyestuff or processes required to achieve certain hues weaken the fibers of the wool. Some of these effects are regarded as detrimental to the carpet, some are found desirable, and some are a matter of degree, debate, or taste. The bleeding of colors and rapid fading are undesirable, since they are found to upset the harmony of the colors or obscure design through loss of contrast. The aging processes through which colors settle, mellow, or soften are generally highly sought-after aesthetic effects. Dyes that produce dark colors tend to weaken the wool and erode the pile quicker than other dyes. This can create a so-called relief effect, where the darker areas in the design have lower pile than the lighter areas. At a certain point, the darker pile disappears altogether, disrupting the structure of the rug. The relief effect (normally) attests to a certain age and is considered natural and interesting. In fact, it is sometimes imitated by cutting the pile of darker wool more than the surround pile. It might indicate either the use of natural dyes (and traditional craftsmanship) or early synthetic dyes. Both attest to a certain age, but are usually judged differently.

Another physical property of carpets relating to color - but not directly, at least, a sign of age - is abrash: variations in color. A field of yellow in a design may have slight variations in the shade of yellows in horizontal lines. This effect is usually found on so-called tribal or village carpets, which rely on small-scale production. In rural settings yarn is dyed in small batches and each batch tends to vary slightly in colors because the dyeing process is difficult to control and replicate, especially with natural dyes. Abrash might be perceived as either an imperfection, resulting from sloppiness, or a hallmark of traditional folk arts, which gives the rug uniqueness, charm, and spirit. Abrash might be an indication of age, since most recent carpet production is based on larger-scale, centralized dyeing using more standardized and controllable synthetic dyes. But here we find that the effect can also be produced deliberately to imitate more primitive and older rugs for commercial purposes.

There are many indicators of the age of carpets other than those pertaining to color. Some are clearly related to natural processes of wear and decomposition (sheen, thickness of pile, integrity of structure); others depend on accumulated knowledge about the craft and design 
traditions of different regions and eras. Certain combinations of spinning, knotting, or weaving techniques, sizes, stylistic elements, or other properties are known to be characteristic for a given region and era of production. We might ask whether such combinations can be considered patina as a physical property. They are not 'direct' and 'natural' signs of age, but still evidence of a rug's origin in time and space. They represent a more indirect connection between object and age than the patina discussed by McCracken.

This points to the difficulty in distinguishing physical properties from symbolic properties of cultural goods. And it also brings us back to McCracken's notion of 'invisible ink,' the 'hidden' codes of status symbolism that enable distinction and social exclusion.

Anyone entering the world of oriental carpets will feel at a loss as to how to make sense of the variety and value of carpets. Unable to make such distinctions, the novice has little idea of what the carpet (or the way the owner talks about or displays it) might reveal about its owner (their wealth, knowledge, or taste). An expert, however, may know more than the owner about the carpet's age, origin, or value and will have a clear idea of how this reflects back on the owner. It is in this sense that we might talk about 'invisible ink' and 'hidden' codes. Bourdieu refers to the 'explicit or implicit schemes of perception and appreciation' in the consumption of cultural goods (1984: 2). It is such schemes, which are not necessarily entirely invisible, that actors apply in investing cultural goods with meaning, value, and capacity for sensory or aesthetic enjoyment.

We discern different approaches to, or (sub)schemes of, perception and appreciation in oriental carpets. Veteran collector Sam Gordon, in a critique of rug scholarship, proposed a distinction between what he calls 'anthropological' or 'ethnological,' 'art-historical,' 'structural,' and 'aesthetic' or 'socio-psychological' approaches to carpets (Gordon 2001). He finds that rug scholars, for whom he expresses great disdain, tend to view carpets through any one of the first three lenses. They neglect the aesthetic gaze, which for him represents genuine appreciation of oriental carpets. While Gordon's classification is sketchy, it does provide a rough framework through which our analysis of modes of perception and appreciation, material and symbolic properties, and evaluative criteria can be further developed.

The 'art-historical' approach goes back to the nineteenth century, when museum curators started to acquire and display classical 
sixteenth- and seventeenth-century carpets. They used knowledge about European paintings displaying oriental carpets with distinctive patterns to approximate the date and origins of fine items in European collections. The ties forged to European fine art and nobility (and perhaps their oriental counterparts) contributed to canonize Safavid, Ottoman, and Mughal carpets.

The so-called 'anthropological' or 'ethnological' approach, meanwhile, valorizes nomad and peasant carpets as authentic representations of the traditional crafts and ways of life of tribal communities. In this view, the simpler and more spontaneous designs embody the folkloristic, primitive, or primordial. Brian Spooner has analyzed the quest for and negotiation of authenticity in the carpet trade, which is most pronounced within this approach. He defines authenticity as a 'conceptualization of elusive, inadequately defined, other cultural, socially ordered genuineness' (Spooner 1986: 225) and argues that, 'because of social expansion recently we have been needing more and more of it' (ibid.). In order to satisfy our need for authenticity, we have altered our criteria for it. The devaluation we have described perhaps suggests criteria of authenticity have reached their lower limit for oriental carpets, or that we have turned to other sources of authenticity.

Referring to the structure and construction of carpets, the 'structural' approach focuses on material properties. Its condition, knot count, regularity, and other more technical qualities are key parameters in appraising its value. It tends, as does the art-historical approach, toward the ideal of classical carpets, favoring products of royal and urban workshops rather than village or tribal arts. However, it is less concerned with provenance and cultural canons.

The 'aesthetic' approach shares the focus of the structural approach on the material qualities of carpets. Or, perhaps more accurately, it is predicated on the capacity of carpets to evoke strong, immediate sensory and emotional gratification in the observer. Rather than the structural aspects, it is the color, texture, and design of the carpet that matter in this approach. While, like the 'anthropological' approach, it values the qualities of more 'primitive' folk art, the aesthetic gaze is less concerned with the carpet's communities of origin, context of production, and ritual uses.

Harry can, like Sam Gordon, be identified with the 'aesthetic' approach: 
To most collectors the physical condition is everything. I am a collector who does not care about condition. I never counted knots.... What excites me is the color contrasts - how colors set each other off. The field, background black, makes colors shine. I like dark colored fields, unlike rookies who like lighter colored fields. I am taken also by elegant simplicity. Bolder splashes of color, a lot of color on an open field.... Well-balanced designs. I also like the tactile aspect. Resilience of the carpet - has to do with good wool.... The thrill is about the beauty of a piece. The skill of the young woman who made it. A piece by a Khamseh woman: she took a three-medallion design, worked in the tradition; but she knew how to make the colors sing; she knew how to work in open space; she did it in muted colors, put in chickens, peacocks.

Consider also an American collector from New York:

I am a visually oriented person. I get rug catalogs from all over the world.... I buy on aesthetics. ... I look and buy, more than read. Of course, knowing what they are improves their aesthetics. I don't care for the technical stuff. I am only interested in tribal arts. .. . Color is important... . I buy fragments too; some fragments are exquisite. .. . I find the devotion, the naiveté in Christ paintings of the Renaissance charming. You find that in carpets! If I could collect cave paintings that's what I'd do.... Primal. Simple, yet so beautiful.

As these collectors' words imply, the four approaches do not represent independent modes of perception and appreciation. All of Gordon's four approaches, with more or less insistence, disavow industrial and mass production methods, direct influence of consumer demand, and trends in interior design and decorative arts. But the approaches vary in terms of which forms of patina they recognize and value higher than others. The aesthetic approach, for instance, values abrash more than the structural approach, and for slightly different reasons than the anthropological approach (visual effect vs. authentic representation of nomadic or village traditions).

The quotes also indicate that the division of material and symbolical (properties) may well be flawed. The provenance and the history of a region or a village or an ethnic group shape not only the symbolic but also the material properties of oriental carpets. Then, the primitive, primal, primordial aspects that collectors and experts value may well offer an extension of McCracken's patina. Perhaps only those carpets which remain unadulterated by (Western) commercial influences and thereby retain a high degree of artistic integrity produce the visual and tactile effects in which the somewhat romantic aesthetic gaze delights. 


\section{Patina meets fashion}

We have used the analysis of patina to explore how material properties, processes, and affordances are connected to the symbolic meaning and evaluations of carpets. This leads us to question the notion of patina as 'natural,' 'material' signs of age, and patina strategies as outmoded ways of employing patina (on) objects to validate status claims.

As stated, McCracken suggests that patina was replaced by fashion as a dominant system of status representation, and plays a marginal role in modern society. The general decline in interest in oriental carpets, as a result of modern styles and ever-changing trends in interior design, seems to confirm this hypothesis. New, fashionable objects have no patina. Patina objects, prestige goods that age gracefully, or goods that become prestigious because they age gracefully, are not in fashion. Yet, our case has presented evidence that fashion and patina, cults of newness and age, mix in odd ways. We saw that there are also fashion trends in old carpets. Periodically, new types of oriental textiles are discovered or rediscovered and become the subject of a periodic surge in collector and market interest. Of course, this may be seen as evidence of the fashion system's hegemony. However, we might view the phenomenon as a special case of Caves' (2000) 'Ars Longa' property of creative industries, which addresses the durability of certain cultural products. The value of fine oriental carpets is expected to increase (amid fluctuations) over an extended time period. We can also find creativity and innovation in old carpets. The accumulation of patina on objects means that they, in a sense, live. Since carpets undergo gradual transformation over time, the aesthetic consequences of choices in materials and design may become fully evident only decades after carpets are finished. Also, as the schemes of perception and appreciation develop over time, or collectors or experts with an eye for finer details come across forgotten items, innovative breaks from tradition, or creative executions that push traditions, are discovered in the old. Harry imagines the Khamseh woman who wove one of his carpets, as he revels in her innovations and extensions of traditions:

The best ladies go one step beyond tradition but are still embedded in tradition. There is a limited repertoire of designs. I actually place a lot of value on novelty. The Khamseh lady I mentioned - the major overall Gestalt is set by tradition - she copies a design, then incorporates in her own other stuff. Nothing is made from nothing. Innovation is limited, within genre. 
But we may argue that it is not only fashion and innovation that are found in markets for patina objects; patina also imposes itself in the fashion system. We suggested that the notion of patina could be extended to signs of age or allusions to past forms and styles that are arbitrary (symbolic) rather than 'natural' or 'direct' (iconic). If we think of patina even more broadly, we might think of concerns of modern corporations (in not only luxury and fashion) with authenticity, nostalgia, heritage, and retro styles as a kind of patina effect. Chapters 4 and 5 in this volume hint at this.

What is the appeal of patina today, then? Patina objects, as McCracken suggests, probably play a marginal role in status representation in contemporary society. As noted with Appadurai (1996: 76), we doubt whether the subtle shift of patina from object to owner ever worked as smoothly in practice as in theory.

However, the complex and subtle shifts certain objects undergo over the course of time inspire actors to engage with them. These actors assign symbolic meaning and value to things and their aging processes. Or, put differently, the material properties and processes lend themselves particularly well to, or afford, various symbolic uses. The symbolic properties and value of patina objects include identity value (expressing self-concept and social position) and linking value (facilitating or communicating social communion and group membership), apart from, of course, economic (market price) and cultural value (cultural and historical significance). We have stressed the role of more or less 'invisible ink' or schemes of perception and appreciation in mediating between objects and actors and between actors. We might ask how central these schemes are for the appreciation of oriental carpets. Finer, old pieces seem to be capable of inspiring a powerful sense of delight and even awe. One of the expressions of patina in carpets is sheen, which brings associations of aura. And it is perhaps an auratic effect that patina brings to objects. Patina objects evoke direct and immediate responses, perhaps not by virtue of the material properties themselves but because patina validates a whole set of associations between carpets and scarcity, singularity and uniqueness, ritual uses, heritage, history, and myths. Moreover, just as the material and the symbolic are embedded in each other, the new and the old, fashion and patina can also be in dialog with each other - in carpets, music, fashion clothing, and so on. Not only oriental carpets but many other cultural and artistic objects of the Other, such as African masks 
(Torgovnick 1990), provide contemporary consumers with the means to enact their modern tastes and their search for authenticity. Such objects become status markers as objects of another time and space, as well as being objects of fashion. Patina and fashion, the past and the present, interact.

\section{References}

Appadurai, Arjun. 1996. Modernity at Large: Cultural dimensions of globalization. Minneapolis: Minnesota University Press.

Belk, Russell W. 1988. Possessions and the extended self. Journal of Consumer Research 15 (2): 139-168.

Bourdieu, Pierre. 1984. Distinction. A social critique of the judgment of taste. Cambridge, MA: Harvard University Press.

Caves, R. E. 2000. Creative Industries: Contracts between art and commerce. Cambridge, MA: Harvard University Press.

Csaba, Fabian F. and Güliz Ger. 2000. Global village carpets: marketing, tradition and the oriental carpet renaissance. In Marketing Contributions to Democratization and Socioeconomic Developments, ed. Clifford J. Schultz and Brune Grbac, pp. 138-152. Arizona State University.

Eiland, Murray L. III. 1993. The past re-made: the case of oriental carpets. Antiquity 67 (257): 859-863.

Eiland, Murray L. III and Murray Eiland, Jr. 1998. Oriental Carpets. A Complete Guide, 4th Edition. New York: Bulfinch Press.

Ger, Güliz and Fabian F. Csaba. 2000. Flying carpets: the production and consumption of tradition and mystique. In Advances in Consumer Research, Vol. XXVII, ed. Stephen J. Hoch and Roben J. Meyer, pp. 132-137. Provo, UT: Association for Consumer Research.

Gordon, Sam. 2001. Collector and literature. Ruglore. Online at: http://home. earthlink.net/ gordsa/page11.html, retrieved 2011-05-12.

McCracken, Grant. 1988. Culture and Consumption. New approaches to the symbolic character of consumer goods and activities. Bloomington and Indianapolis: Indiana University Press.

Opie, James. 1998. Starting over: the 1990s rug revival. Hali 100 (20): 199-203.

Spooner, Brian. 1986. Weavers and dealers: the authenticity of an oriental carpet. In The Social Life of Things, ed. Arjun Appadurai. Cambridge: Cambridge University Press.

Torgovnick, Marianna. 1990. Gone Primitive: Savage intellects, modern lives. University of Chicago Press. 